\title{
Rancang Bangun Sistem Informasi Penerimaan Karyawan Di PT. Asta Pilar Gemilang Jakarta
}

\author{
Ade Suryanto $^{1)}$ dan Muhammad Dinul ${ }^{2)}$ \\ Jurusan Teknik Industri dan Sistem Informasi, Fakultas Teknik dan Informatika, Universitas Bina Sarana \\ Informatika, Jl. Kramat Raya No.98, RT.2/RW.9, Kwitang, Senen, Jakarta Pusat, \\ DKI Jakarta 10450, Indonesia \\ 1) ade.ayo@bsi.ac.id \\ mdinul79@gmail.com
}

\begin{abstract}
Abstrak. Sistem komputerisasi dan terintegrasi dengan sistem lainnya akan sangat membantu untuk mendukung berjalannya roda perusahaan dan mampu bersaing dengan perusahaan lainnya. PT Asta Pilar Gemilang Jakarta saat ini masih menjalankan sistem konvensional dalam merekrut karyawannya, sehingga proses dari awal penerimaan hingga seleksi karyawan dibutuhkan proses yang lama, serta informasi ketersediaan lowongan pekerjaan disampaikan juga secara tradisional dari pihak internal ke eksternal dengan cara komunikasi verbal, tidak memanfaatkan teknologi informasi ataupun media sosial. Metode waterfall diterapkan untuk menyelesaikan permasalahan yang ada, dimulai dari analisis kebutuhan, desain sistem, pengkodean, penerapan sampai pemeliharaan sistem. Desain sistem memakai UML, dan mempraktikkan teknologi berbasis website yang terdiri dari bahasa pemrograman PHP, basis informasi MySQL dan teknologi bootstrap untuk antar muka yang responsif. Hasilnya adalah tercipta sistem penerimaan karyawan yang responsif, efisien dan efektif. Para pelamar dapat mengisi profil dan mengirim data lamarannya ke sistem yang telah disediakan, sehingga perusahaan dapat langsung melihat data pelamar, hingga menyeleksi serta memberikan informasi ke pelamar secara real time. Sistem ini mampu memberikan suatu solusi terbaik terhadap masalah yang ada, dan memberikan hasil yang akurat untuk perusahaan dalam memberikan suatu keputusan dan kenyamanan para pencari kerja.
\end{abstract}

Kata kunci: sistem informasi pekerjaan, lowongan kerja, $U M L$

\begin{abstract}
Computerized systems and integrated with other systems will greatly help support the company's wheels and be able to compete with other companies. PT Asta Pilar Gemilang Jakarta is currently still running a conventional system in recruiting its employees, so the process from initial recruitment to employee selection requires a long process, and information on job vacancies is also traditionally conveyed from internal to external parties by means of verbal communication, not utilizing technology information or social media. The waterfall method is applied to solve existing problems, starting from requirements analysis, system design, coding, application to system maintenance. The system design uses UML, and practices website-based technology consisting of the $P H P$ programming language, MySQL information base and bootstrap technology for a responsive interface. The result is a responsive, efficient and effective employee recruitment system. Applicants can fill out a profile and send their application data to the system provided, so that companies can immediately see the applicant's data, to select and provide information to applicants in real time. This system is able to provide the best solution to existing problems, and provide accurate results for companies in providing a decision and comfort for job seekers.
\end{abstract}

Keywords: job information system, job openings, UML

\section{Pendahuluan}

Sulitnya mendapatkan pekerjaan seakan menjadi masalah yang tidak pernah habisnya di sekitar kita. Tingkat pendidikan yang tinggi dan kelulusan yang baik ternyata tidak bisa di jadikan jaminan untuk mendapatkan pekerjaan yang sesuai dengan latar belakang dan keinginan.
Hal ini terbukti dari tingginya tingkat pengangguran terbuka (TPT) Agustus 2020 sebesar 7,07 persen, meningkat 1,84 persen poin dibandingkan dengan Agustus 2019(dikutip dari https://www.bps.go.id). Apapun saat ini kita dapat 
Jurnal Pendidikan dan Aplikasi Industri (UNISTEK)

Vol. 8 No.1 Februari 2021

p- ISSN : 0126 - 4036

e- ISSN : 2716 - 0416

lihat bahwa teknologi berperan sangat penting memajukan institusi, lembaga atau perusahaan karena

kebutuhan dan tuntutan kemajuan jaman yang mengharuskan segalanya dilakukan dengan cepat, tepat, cermat, efektif dan akurat. Para pelamar kerja, biasanya pada beberapa kasus mereka mendapat informasi melalui perantara teman kerja atau kerabat. Hak demikian menjadi kendala karena pelamar setidaknya membawa segala kelengkapan berupa berkas atau dokumen sebagai persyaratan melamar kerja, seperti surat lamaran kerja, dokumen ijazah pendidikan, akte lahir, salinan berkas lainnya yang dibutuhkan sesuai syarat dari perusahaan. Kemungkinan dari beberapa dokumen tersebut akan mengalami kerusakan saat dibawa dalam perjalanan sebelum sampai ke tujuan.

Tujuan dari dibangunnya sistem ini yaitu untuk memberikan kemudahan para pelamar untuk mencari pekerjaan serta efisiensi dalam menyebar informasi ketersediaan pekerjaan yang dibutuhkan oleh penyedia pekerjaan, sehingga detail dari informasi yang disuguhkan dapat diterima secara cepat dan akurat oleh pelamar kerja.

Pada penelitian sebelumnya terkait dengan sistem penerimaan karyawan yaitu: diambil dari (Anisah, Anton, \& Radiyah, 2016) dengan judul Rancangan Sistem Informasi E-Recruitment Berbasis Web Pada PT.Geoservices, dimana proses pencarian calon karyawan dirasa masih kurang berjalan secara efektif dan butuh biaya yang tidak sedikit, sehingga terjadi tumpukan berkas, boros pemakaian ruangan hingga polusi lingkungan. Diambil dari sumber lainnya yaitu artikel (Nurmaesah, Tobing, \& Andari, 2019) yang bertema Perancangan Sistem Informasi ERecruitment Karyawan pada PT Far East Conmix Indonesia, menjelaskan proses penerimaan pegawai masih dilakukan secara mandiri,sehingga solusi terbaik dalam hal ini membangun sistem berbasis web untuk kemudahan serta efisiensi biaya operasional.

\section{Bahan dan Metode: Pengertian Sistem}

Menurut Sutabri dalam Anggraeni (2017:11) "sistem dapat memiliki makna sebagai suatu himpunan dari elemen, unsur, komponen atau variable yang terkoordinir, terintegrasi, berinterkasi dan tidak dapat dipisahkan dengan lainnya.".

Menurut Sanjaya (2015:2), bahwa:

Sistem dapat diartikan sebagai satu kesatuan komponen-komponen yang saling berhubungan untuk mencapai tujuan tertentu. Dari konsep tersebut,ada tiga ciri utama suatu sistem, antara lain memiliki tujuan tertentu, memiliki fungsi tertentu dalam pencapaian tujuan sistem dan untuk menjalankan fungsinya sistem didukung oleh berbagai komponen.

Menurut Hutahaean (2015:2), menjelaskan "Sistem merupakan prosedur yang membentuk suatu jaring kerja yang saling berinteraksi, terkumpul menjadi satu untuk menjalankan kegiatan dalam mencapai tujuan tertentu".

Menurut Djahir \& Pratita (2015:7), "mendetailkan sistem ke dalam dua bagian, pertama yaitu bagian yang fokus terhadap prosedur dan kedua fokus terhadap elemennya".

Menurut Romney dan Steinbart dalam Mulyani (2016:2) menjelaskan sistem merupakan himpunan dari dua atau lebih dari komponen yang saling berinteraksi untuk mencapai suatu sasaran dan tujuan spesifik".

Menurut Hutahaean (2015:3), menjelaskan bahwa karakteristik sistem yang handal itu memiliki:

\section{Komponen}

Sistem merupakan sejumlah komponenkomponen yang saling berkomunikasi, artinya saling bekerja sama membentuk satu kesatuan. Komponen memiliki subsistem atau bagian-bagian dari sistem.

\section{Batasan Sistem (Boundary)}

Boundary merupakan pembatas yang membatasi sistem dari lingkungan luarnya, dapat dilihat sebagai satu kesatuan serta memperlihatkan lingkup dari sistem itu sendiri.

\section{Lingkungan Luar Sistem (Environment)}

Lingkungan Luar Sistem merupakan batas luar dari suatu sistem yang sanggup memberi dampak berjalannya sistem. Tetap harus dipelihara dan dijaga jika memberi keuntungan serta harus dikendalikan jika merugikan supaya sistem dapat bertahan hidup lebih lama.

\section{Penghubung Sistem (Interface)}

Interface adalah perangkat komunikasi antara subsistem. Memberikan alternatif aliran sumber daya mengalir antar subsistem. Luaran dari subsistem akan menjadi suatu masukan terhadap subsistem lain dengan perantara penghubung.

\section{Masukan Sistem}

Masukan sistem yaitu daya yang dialirkan ke sistem, dapat berbentuk masukan pemeliharaan dan sinyal yang masuk. Masukan pemeliharaan merupakan energi yang dialirkan supaya sistem dapat berjalan. Sinyal masukan merupakan daya yang diolah untuk memperoleh luaran. Sebagai misal, pada sistem komputer, program merupakan masukan pemeliharaan dan data merupakan sinyal masukan agar dapat diproses menjadi suatu informasi.

\section{Keluaran Sistem}

Output merupakan luaran dari proses olah energi serta dikelompokkan menjadi sesuatu yang bermanfaat, misalnya komputer yang mengeluarkan suhu panas yang harus dibuang dan informasi merupakan luaran hasil oleh informasi yang diperlukan.

\section{Proses}

Sistem akan menjadi suatu pengolah yakni dengan cara merubah input menjadi output. Sistem 
komputerisasi akan mengolah data menjadi informasi yang berguna atau sistem akuntansi akan memproses data menjadi berbagai bentuk laporan-laporan keuangan.

\section{Sasaran Sistem}

Sasaran sistem sudah pasti dimiliki suatu sistem. Penentuan masukan menjadi sangat diperlukan oleh sistem untuk dapat menghasilkan luaran yang sesuai.

\section{Klasifikasi Sistem}

Sistem adalah suatu wujud dari integrasi antar komponen-komponen disebabkan suatu sistem mempunyai tujuan yang tidak sama pada tiap keadaan. Menurut Hutahaean (2015:6), dapat dikelompokkan dalam beberapa kelompok, antara lain:

\section{Klasifikasi sistem sebagai:}

1. Sistem Abstrak

Sistem abstrak adalah sistem yang dihasilkan dari gagasan yang tidak terlihat secara kasat mata atau ide yang abstrak.

2. Sistem Fisik

Sistem fisik adalah sistem yang terlihat oleh fisik mata.

\section{Sistem diklasifikasikan sebagai:}

1. Sistem Alamiah

Yaitu sistem yang dihasilkan akibat dari tindakan alam tanpa campur tangan manusia, contohnya rotasi bumi.

2. Sistem Buatan Manusia

Adalah sistem yang dihasilkan dari campur tangan manusia dengan mesin.

\section{Sistem diklasifikasikan sebagai:}

1. Sistem Tertentu

Merupakan sistem berjalan yang memiliki tingkah laku dapat diketahui dan luarannya dapat diramalkan

2. Sistem Tak Tentu

Merupakan sistem dengan keadaan yang tidak mampu diprediksi karena memiliki unsur probalilitas.

\section{Sistem diklasifikasikan sebagai:}

\section{Sistem Tertutup}

Merupakan sistem yang tidak mendapat pengaruh dari luar sistem, tanpa keterlibatan lingkungan eksternal mampu bekerja sendiri. Teoritisnya sistem ini ada, namun tak satupun sistem yang keberadaanya murni tertutup(sistem tertutup relatif).

2. Sistem Terbuka

Merupakan sistem yang berkaitan dan mendapat pengaruh dari lingkungan luar. Sistem mendapat masukan dan keluaran dari lingkungan eksternalnya dan wajib memiliki kontrol yang baik.

\section{Definisi Program}

Harumy et al (2016:4) berpendapat, "Program adalah formulasi sebuah algoritma dalam bentuk bahasa pemrograman, sehingga siap untuk dijalankan pada mesin komputer".

Program menurut Kadir (Fadallah \& Rosyida (2018:61) "Adalah kumpulan instruksi yang digunakan untuk mengatur komputer agar melakukan suatu tindakan tertentu".

Dapat ditarik kesimpulan mengenai definisi program, yaitu merupakan himpunan perintah yang tersusun,terstruktur dan siap untuk dioperasikan di mesin atau komputer.

Tahapan untuk membuat program menurut Amborowati (Febriani \& Hidayati (2017:262)) antara lain:

1. Mendetailkan permasalahan

2. Menentukan bahasa program yang dibutuhkan

3. Mendesain program

4. Pengkodean

5. Pengujian program dan pelacakan eror

6. Pendokumentasian program

\section{Basis Data}

Menurut Sukamto \& Shalahuddin (2016:43) "Basis data adalah sistem terkomputerisasi yang tujuan utamanya adalah memelihara data yang sudah diolah atau informasi dan membuat informasi itu tersedia saat dibutuhkan". Jadi database merupakan perangkat untuk menyimpan data supaya mudah dan cepat untuk gunakan serta diakses.

Sistem Manajemen Database adalah suatu sistem aplikasi yang digunakan untuk menyimpan, mengelola dan menampilkan data(Sukamto \& Shalahuddin (2016:44)).

Menurut Parulian (2018:2) "Mysql adalah sistem manajemen database yang digunakan untuk menyimpan data dalam tabel terpisah dan menempatkan semua data dalam satu gudang besar". Sedangkan XAMPP adalah singkatan dari masing-masing hurufnya adalah:

$\mathrm{X}=$ perangkat lunak dapat beroperasi di sistem multi platform(Linux,Windows,MacOS dan sejenisnya) A = Apache adalah server website

$\mathrm{M} \quad=$ Mysql adalah server basis data

$\mathrm{P}=$ bahasa program yang digunakan adalah PHP

\section{Model Pengembangan Perangkat Lunak}

Menurut Sukamto \& Shalahuddin dalam (Jariyah \& Yanto, Hasta, 2018), waterfall memiliki sebutan lainnya yaitu model linier sekuensial. Langkah-langkah model ini antara lain:

\section{Analisa Kebutuhan}

Semua persyaratan perangkat lunak pada tahapan ini sudah mesti terpenuhi, manfaat serta boundary perangkat lunak sudah jadi harapan para pengguna. Informasi dengan mudah didapatkan dengan cara tanya jawab hingga survey ke lapangan, lalu hasilnya di analisis untuk memenuhi keperluan dari pengguna menuju proses selanjutnya.

\section{Desain Sistem}

Tahapan ini dimaksudkan sebagai gambaran untuk menentukan langkah selanjutnya yang harus di ambil, seperti mendetailkan keperluan perangkat keras dan bentuk desain sistem mana yang harus di jelaskan 
secara menyeluruh.

\section{Implementasi}

Tahapan ini dilakukan dengan cara memisahkan perangkat lunak menjadi bagian atau modul-modul program lalu disatukan kembali pada tahapan selanjutnya. Serta dijalankan pengecekan modul yang sudah tercipta(lolos fungsi kontrol kendali).

\section{Pengujian}

Tahapan berikutnya yakni menyatukan modul yang telah terbentuk, dilakukan tes untuk tahu perangkat lunak yang tercipta sudah sesuai harapankah, atau masih ada eror, jika terdapat kesalahan harus segera diperbaiki.

\section{Operasi dan Pemeliharaan}

Tahapan terakhir dalam model air terjun ini yaitu operasi dan pemeliharaan. Perangkat lunak atau aplikasi yang sudah tercipta dioperasikan dan di jalankan sistem pemeliharaan antara lain perbaikan eror atau bug yang tak dapat didefinisikan pada fase sebelumnya, Perbaikan pada tahapan implementasi sistem serta meningkatkan jasa sistem untuk pemenuhan kebutuhan baru.

\section{ERD (Entity Relationship Diagram)}

Yulia (2017:28) berpendapat, ERD menggunakan pendekatan atas-bawah untuk mendesain basis data, diawali identifikasi data pokok(entitas) dan hubungan antara data yang harus djelaskan ke bentuk model. Lalu disisipkan beberapa atribut, Batasan entitas dan relasi.

Yanto (2016:32) beropini bahwa ERD memiliki tiga komponen pokok, antara lain:

\section{Entitas}

Yaitu objek yang ada didunia, dapat didefinisikan dari objek lain disekitarnya, dapat berbentuk objek bernyawa(manusia) hingga objek atau bentuk lainnya(sistem).

\section{Atribut}

yaitu informasi yang melekat pada objek atau entitas. Sebagai contoh misalnya objek manusia memiliki atribut nama, tanggal lahir, alamat dan seterusnya.

\section{Relasi}

Merupakan konektor antar entitas, dimulai dengan kata kerja untuk menjelaskan keterkaitannya.

\section{LRS (Logical Record Structure)}

Septihandayani \& Yuniva (2016:28) menjelaskan "Logical Relationship Structure merupakan model sistem yang dicitrakan melalui gambar atau diagram dengan simbol tertentu, diagram ini akan mengikuti aturan pemodelan yang spesifik berkaitan dengan perubahan ke LRS".

Menurut Junaidi (2016:18) "LRS merupakan luaran dari pemodelan suatu relasi entitas disertai dengan propertinya, hingga dapat ditemukan kaitan antara entitas tersebut".

\section{UML (Unified Modelling Language)}

Mulyani (2016:244) berpendapat bahwa UML merupakan sebuah bahasa pemodelan grafik yang dapat dimanfaatkan sebagai bentuk standar pemodelan sistem dengan metodologi pemodelan yang fokus ke objek.

Sukamto \& Shalahuddin (2016:137) berpendapat bahwa UML adalah bahasa yang dapat ditampilkan ke bentuk model yang dapat berinteraksi dengan sebuah sistem melalui perantara diagram serta teks pendukung lainnya. UML memiliki empat varian yang khusus antara lain Diagram Interchage Specification, UML Infrastructure, UML Superstructure, dan Object Constraint Language. Pada gambar 1 dibawah, UML terbagai dalam 3 kategori dan memiliki 13 varian diagram.

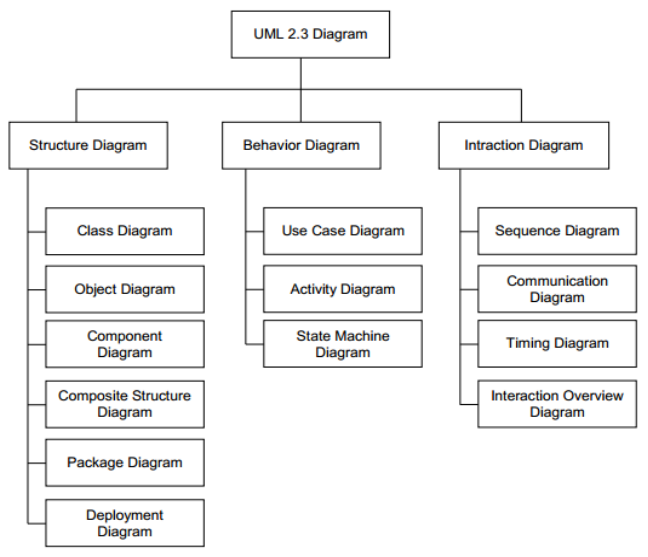

Gambar 1. Diagram UML

\section{Diagram Aktifitas}

Menurut Sukamto \& Shalahuddin (2016:161) "Diagram aktivitas atau activity diagram menggambarkan workflow (aliran kerja) atau aktivitas dari sebuah sistem atau proses bisnis atau menu yang ada pada perangkat lunak". Menjadi catatan, bahwa diagram aktivitas menjelaskan kegiatan sistem, tidak memberi penjelasan atas kegiatan aktor di dalam sisteem. Diagram ini sering dimanfaatkan untuk menjelaskan banyak hal antara lain 1)mendefinisikan proses bisnis, yang mana prosesnya yang didefinisikan, 2)susunan dari view sistem atau antarmuka, yang mana setiap kegiatan merupakan antarmuka, 3)desain testing, merupakan kegiatan yang menganggap tiap kegiatan membutuhkan tes yang dapat didetilkan kasus tesnya.

\section{Use case Diagram}

Menurut Sukamto \& Shalahuddin (2016:155) "Use case diagram merupakan pemodelan untuk kelakuan (behavior) sistem informasi yang akan dibuat". Diagram ini menjelaskan hubungan antar aktor dalam sistem yang akan dibangun. Aktor menerangkan objek manusia, proses maupun sistem yang berkomunikasi dengan sistem. Jadi aktor tidak mesti suatu objek manusia. Use case sendiri merupakan fungsionalitas yang telah ada di sistem, perannya sebagai unit yang dapat melakukan perpindahan message antar unit atau objek aktor.

\section{Diagram Kelas}

Sukamto \& Shalahuddin (2016:141) berpendapat bahwa Diagram kelas mencirikan susunan sistem dari sudut definisi tiap kelas yang digunakan untuk mendesain sistem. Susunannya mempunyai beberapa 
Jurnal Pendidikan dan Aplikasi Industri (UNISTEK)

Vol. 8 No.1 Februari 2021

p- ISSN : 0126 - 4036

e- ISSN : 2716 - 0416

jenis kelas, antara lain:

1. Main class

Kelas dimana sistem akan mulai dijalankan yakni ketika fungsi main di awal.

2. View class

Kelas ini yang akan mengkoordinasikan antar muka tampilan ke pengguna.

3. Controller class

Penanganan segala fungsi dari pendeskripsian use case adalah tugas controller class. Jenis ini yang akan mengolah bisnis proses pada software.

4. Model class

Berperan sangat penting yang akan menjadikan satu semua data yang diolah, mulai dari input hingga simpan data ke database.

\section{Diagram Sekuen}

$\begin{array}{cccr}\begin{array}{c}\text { Sukamto } \\ \text { berpendapat }\end{array} & \begin{array}{c}\text { Shalahuddin } \\ \text { bahwa }\end{array} & \text { Sequence } & \text { diagram }\end{array}$ mendeskripsikan perilaku objek pada use case dengan mendeskripsikan waktu hidup objek dan message yang dikirimkan dan diterima antar objek".

Diagram sekuen akan Digambar sesuai dengan jumlah diagram use case yang ada dalam sistem, setidaknya pendefinisian komunikasi aliran message sudah termasuk di diagram sekuen, sehingga kian banyak angka use case yang dideskripsikan, maka pembuatan diagram sekuen otomatis mengikuti jumlahnya juga.

\section{Hasil dan Pembahasan Metode Penelitian Analisis Kebutuhan}

Dikutip dari Yurindra (2017:43), tahapantahapan dari metode waterfall antara lain analisa kebutuhan sistem, desain sistem, implementasi sistem, integrasi dan pengujian sistem hingga pemeliharaan adalah pengembangan perangkat lunak yang dijalankan untuk memberikan jawaban atas masalah yang dihadapi.

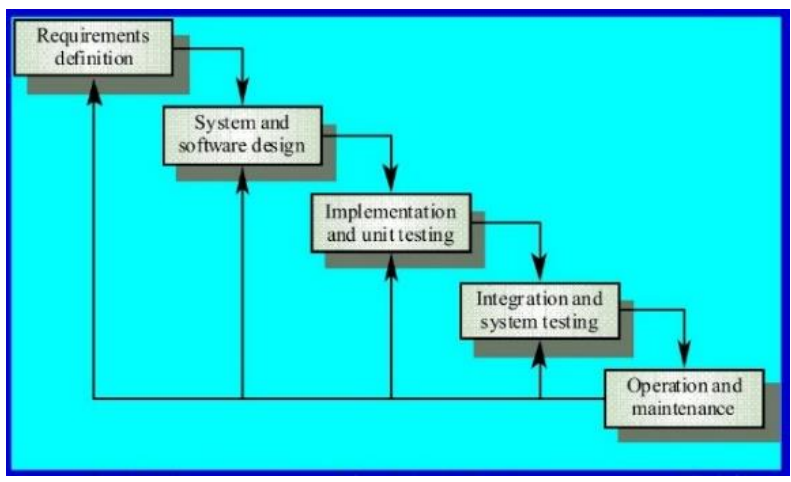

Gambar 2. Konsep Waterfall

Sistem penerimaan pegawai baru akan diberikan kemudahan dalam melakukan kegiatan melamar pekerjaan, calon pegawai tak perlu direpotkan berkunjung ke perusahaan penyedia lowongan kerja untuk melamar, mereka cukup mendaftar dan mengakses lama situs perusahaan melalui daring dengan koneksi internet, kapan dan dimanapun pelamar berada dengan menggunakan gawai mereka masing-masing. Beberapa hal yang menjadi kebutuhan dari sistem penerimaan pegawai di perusahaan, antara lain:

\section{Kebutuhan Pengguna}

Pada sistem penerimaan pegawai ini terdiri dari dua pemakai, mereka saling berkomunikasi di dalam sistem, yakni admin dan pelamar kerja. Masingmasing mempunyai sifat interaksi yang mirip namun ada hal-hal yang menjadi perbedaan untuk tiap pengguna, antara lain:

1. Skenario Kebutuhan Bagian Administrasi

2. Pengolahan data-data jabatan atau karir

3. Pengelolaan data para pelamar kerja

4. Pengelolaan data semua laporan

5. Skenario Pelamar

6. Pelamar bisa melihat halaman utama

7. Pelamar bisa melihat profil perusahaan

8. Pelamar bisa melihat kontak perusahaan

9. Pelamar bisa mengisi data untuk melamar

10. Pelamar bisa login sebagai pelamar

\section{Kebutuhan Sistem}

1. Langkah awal yaitu pemakai sistem mesti menjalankan prosedur login untuk bisa masuk ke dalam sistem penerimaan pegawai dengan mengisi kolom nama pengguna serta kata sandi yang sesuai dan valid, hal ini menjadi keharusan dari sistem dalam hal kehandalan sistem.

2. Setelah melakukan kegiatan didalam sistem, para pemakai diharuskan melakukan logout atau keluar dari sistem untuk menjaga keamanan sistem, jangan sampai terjadi kebocoran sistem, dan rusaknya sistem oleh orang yang tidak bertanggun jawab.

3. Pada sistem penerimaan pegawai ini, akan dilakukan filter serta pemilahan data laporan pelamar kerja sesuai dengan kondisi pelamar, apakah lolos atau gagal dalam melamar pekerjaan.

\section{Diagram Usecase Lowongan Kerja}

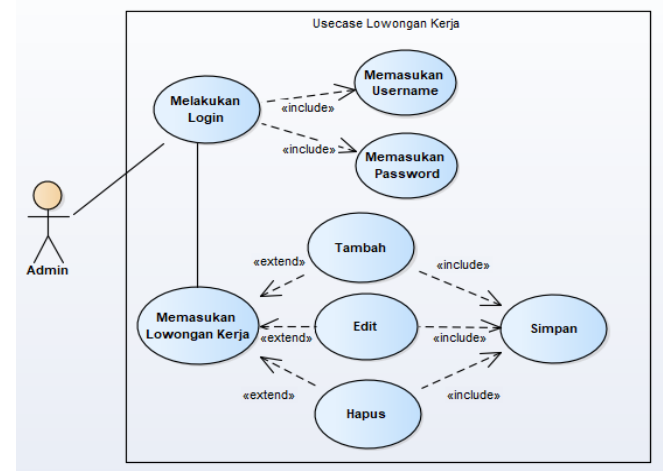

Gambar 3. Usecase Lowongan Kerja

Tabel 1. Deskripsi Usecase Lowongan Kerja

\begin{tabular}{ll} 
Use Case Name & Lowongan Kerja \\
\hline Requirements & Lowongan Kerja Baru
\end{tabular}


Jurnal Pendidikan dan Aplikasi Industri (UNISTEK)

Vol. 8 No.1 Februari 2021

p- ISSN : 0126 - 4036

e- ISSN : 2716 - 0416

\begin{tabular}{ll}
\hline Goal & Penambahan Lowngan Kerja \\
\hline Pre-Conditions & $\begin{array}{l}\text { Bagian Admin telah berhasil } \\
\text { login ke sistem }\end{array}$ \\
\hline Post-Conditions & $\begin{array}{l}\text { Terdapat lowongan kerja } \\
\text { baru yang belum terdata }\end{array}$ \\
\hline $\begin{array}{l}\text { Failed end } \\
\text { Condition }\end{array}$ & Tidak ada data baru \\
\hline Actors & Administrasi \\
\hline Main Flow/ & $\begin{array}{l}\text { Administrasi menginput data } \\
\text { lowongan kerja } \\
\text { Basic Path }\end{array}$ \\
& $\begin{array}{l}\text { Administrasi dapat mengedit, } \\
\text { hapus lowongan keja } \\
\text { Administrasi dapat } \\
\text { mengupload lowongan kerja }\end{array}$ \\
\hline
\end{tabular}

Gambar 4. Usecase Melamar Pekerjaan

Tabel 2. Deskripsi Usecase Melamar Pekerjaan

\begin{tabular}{|c|c|}
\hline Use Case Name & Melamar Pekerjaan \\
\hline Requirements & Pelamar Baru \\
\hline Goal & Penambahan Pelamar \\
\hline Pre-Conditions & $\begin{array}{l}\text { Pelamar kerja telah } \\
\text { berhasil login ke sistem }\end{array}$ \\
\hline Post-Conditions & $\begin{array}{l}\text { Terdapat data diri yang } \\
\text { belum terdata }\end{array}$ \\
\hline $\begin{array}{l}\text { Failed end } \\
\text { Condition }\end{array}$ & Tidak ada data baru \\
\hline Actors & Pelamar \\
\hline $\begin{array}{l}\text { Main Flow/ } \\
\text { Basic Path }\end{array}$ & $\begin{array}{l}\text { 1. Pelamar menginput data } \\
\text { pegalaman kerja kerja } \\
\text { 2. Pelamar menginput data } \\
\text { pegalaman riwayat } \\
\text { pendidikan } \\
\text { 3. Pelamar dapat mengedit, } \\
\text { hapus data diri }\end{array}$ \\
\hline
\end{tabular}

Activity Diagram Registrasi

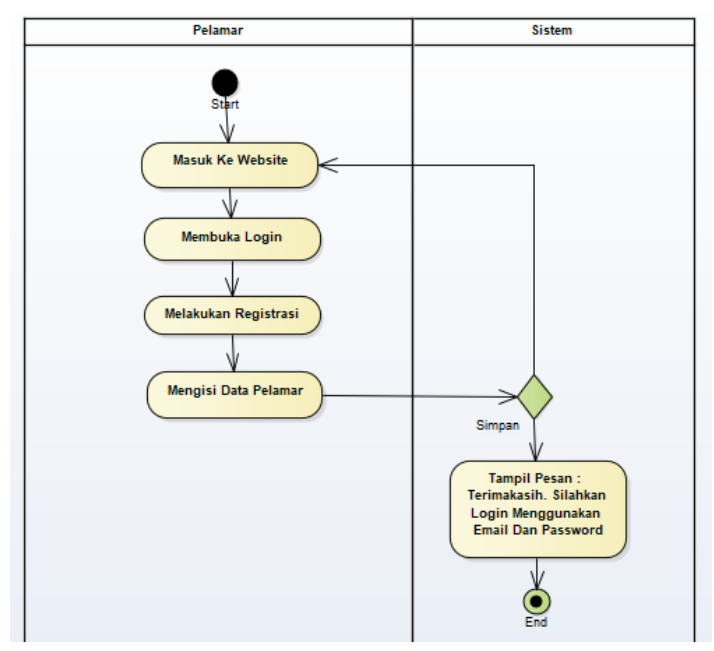

Gambar 5. Activity Diagram Registrasi Activity Diagram administrator

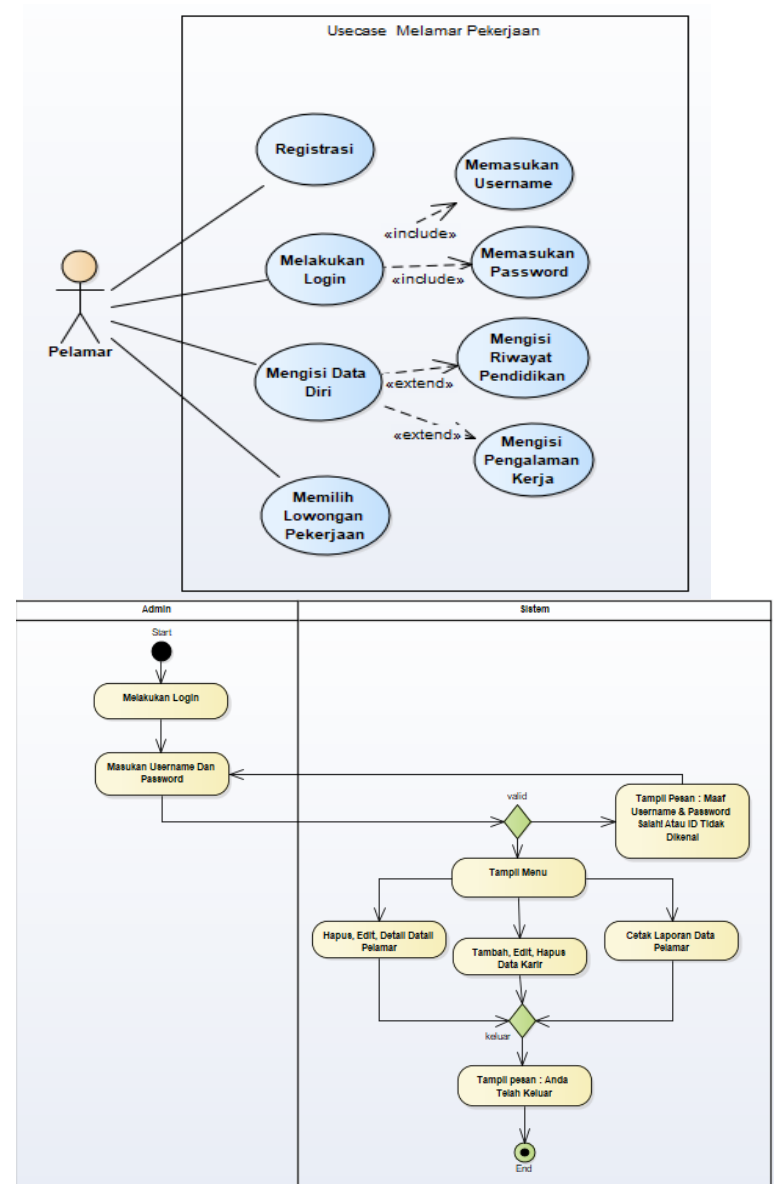

Gambar 6. Activity Diagram Administrator

Activity Diagram Pelamar 
Jurnal Pendidikan dan Aplikasi Industri (UNISTEK)

Vol. 8 No.1 Februari 2021

p- ISSN : 0126 - 4036

e- ISSN : 2716 - 0416

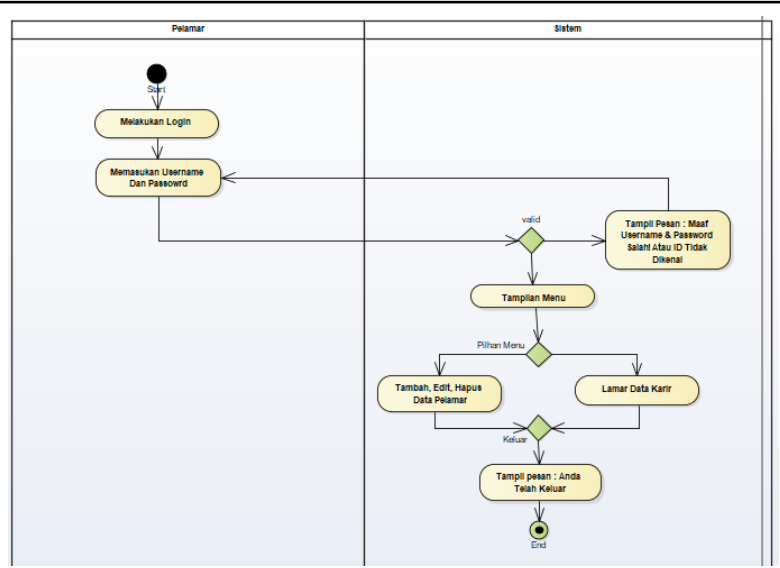

Gambar 7. Activity Diagram Pelamar

Class Diagram sistem penerimaan karyawan

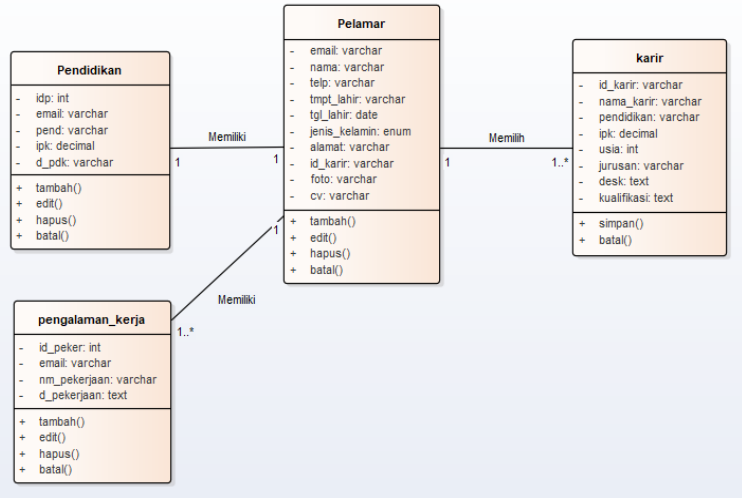

Gambar 8. Class Diagram sistem penerimaan karyawan

Class diagram sistem penerimaan diatas menampilkan class ataupun tabel yang ada dalam aplikasi sistem, terdapat beberapa class atau table antara lain table Pendidikan, pelamar, karir dan pengalaman kerja.

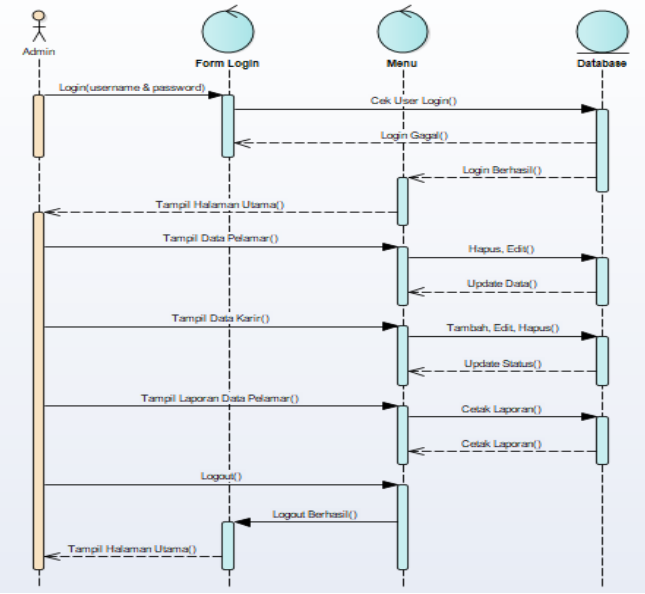

Gambar 9. Sequence Diagram (admin)
Pada sequence diagram dari sisi admin, terdapat 1 boundary life line, 1 actor sebagai pelaku kegiatan yakni admin, 1 control life line yang berinteraksi, beberapa message dan return message yang saling berinteraksi.

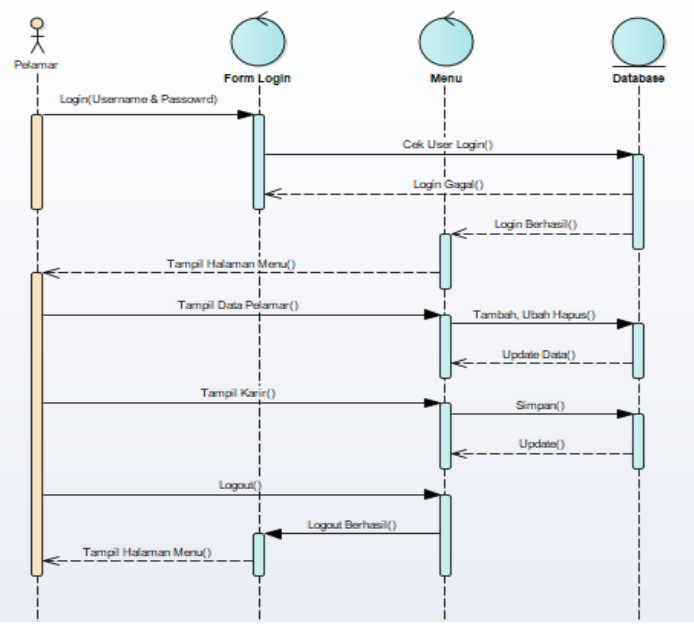

Gambar 10. Sequence Diagram (pelamar)

Pada sequence diagram dari sisi pelamar, terdapat 1 boundary life line, 1 actor sebagai pelaku kegiatan yakni pelamar, 2 control life line yang berinteraksi, beberapa message dan return message yang saling berinteraksi.

\section{Tampilan Rancangan Aplikasi}

Rancangan dibawah ini merupakan interface dari aplikasi sistem rekrutmen sebagai bentuk prototipe yang didesain.

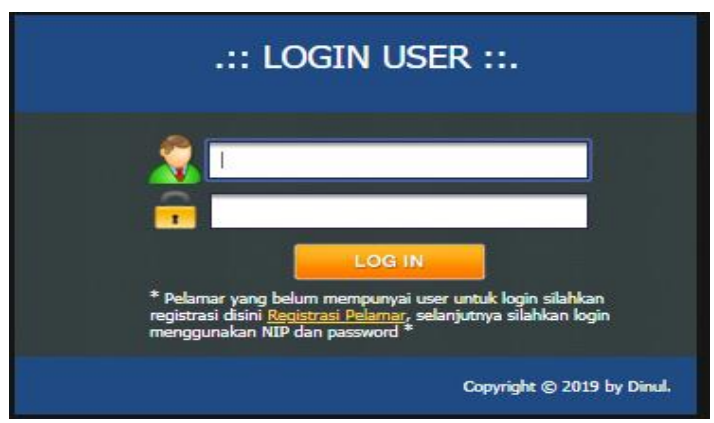

Gambar 11. Halaman Login

Para pengguna dapat melakukan login melalui halaman ini dan jika username dan kata sandi valid, maka sistem akan mengarahkan ke dashboard sesuai levelnya jika sudah terdaftar di sistem, jika pelamar belum registrasi dapat klik tautan registrasi pelamar untuk untuk dapat login ke sistem. 
Jurnal Pendidikan dan Aplikasi Industri (UNISTEK)

Vol. 8 No.1 Februari 2021

p- ISSN : 0126 - 4036

e- ISSN : 2716 - 0416

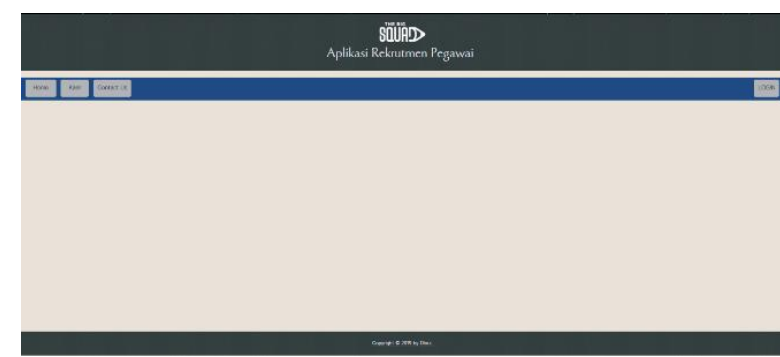

Gambar 12. Halaman Utama

Halaman utama merupakan halaman awal dimana saat dibuka, maka akan terbuka halaman index. Terdapat beberapa menu yaitu home, karir, contact us dan login. Pada menu karir, akan ditampilkan seluruh info lowongan kerja yang ada. Menu contact us menampilkan data kontak perusahaan, menu login menampilkan form login pengguna untuk bisa menggunakan fasilitas yang ada di sistem aplikasi rekrutmen.

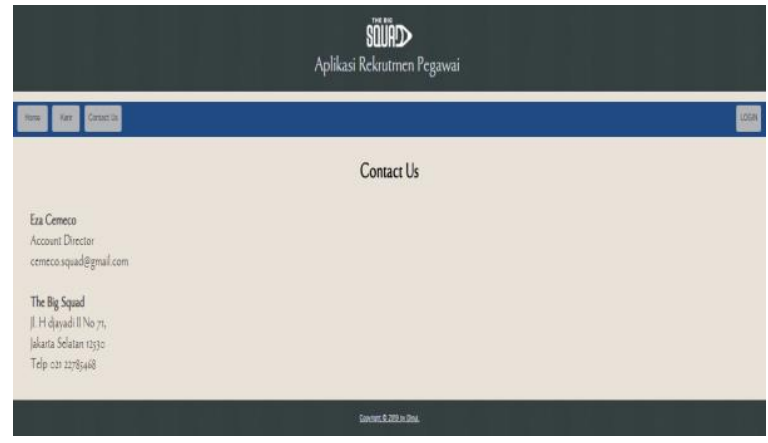

Gambar 13. Halaman contact us

Pada halaman contact us, menampilkan data kontak person perusahaan.

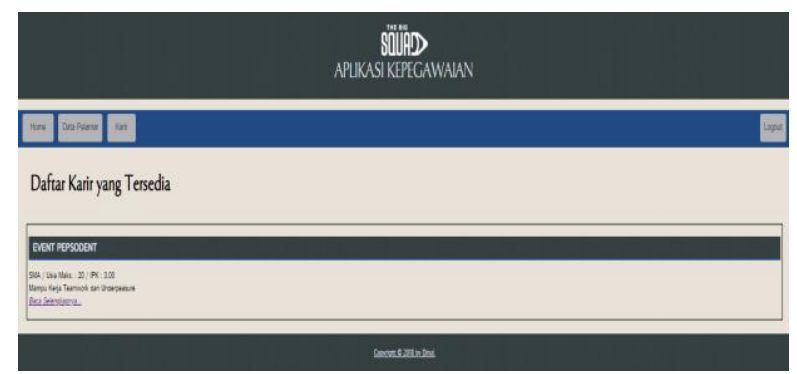

Gambar 14. Halaman Karir

Pada halaman karir, menampilkan semua data lowongan kerja yang ada dari perusahaan. Terdapat tautan detil info karir untuk dapat melihat info pekerjaan secara detil.

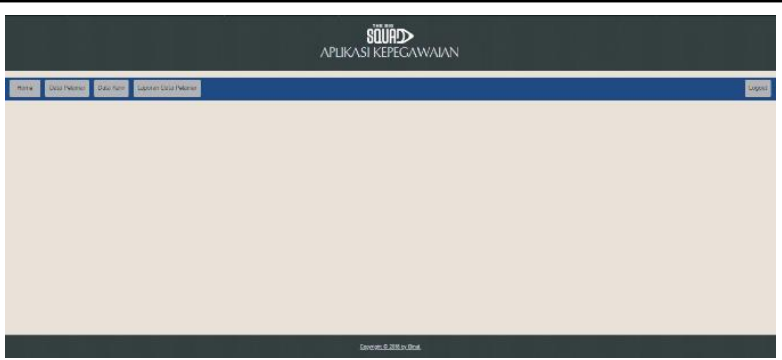

Gambar 15. Dashboard Admin

Jika login sebagai administrator berhasil, maka sistem akan membuka halaman dashboard admin, terdapat beberapa menu antara lain data pelamar, data karir, dan laporan data pelamar.

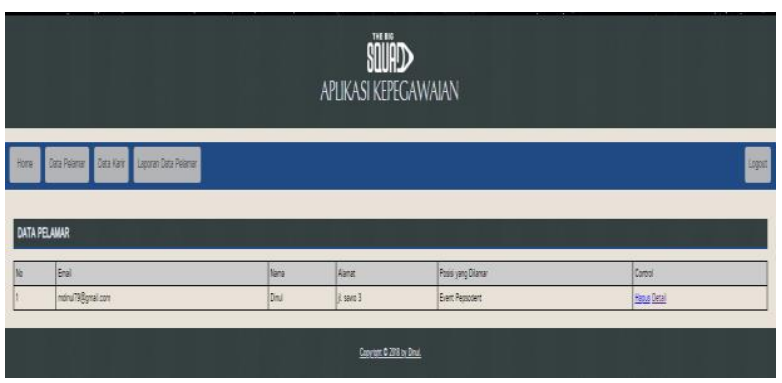

Gambar 16. Halaman Data Pelamar

Pada halaman data pelamar, dita,polkan semua data pelamar yang telah mendaftar di sistem rekrutmen perusahaan, pihak perusahaan akan melihat detil dan ajuan surat pelamar melalui sistem rekrutmen.

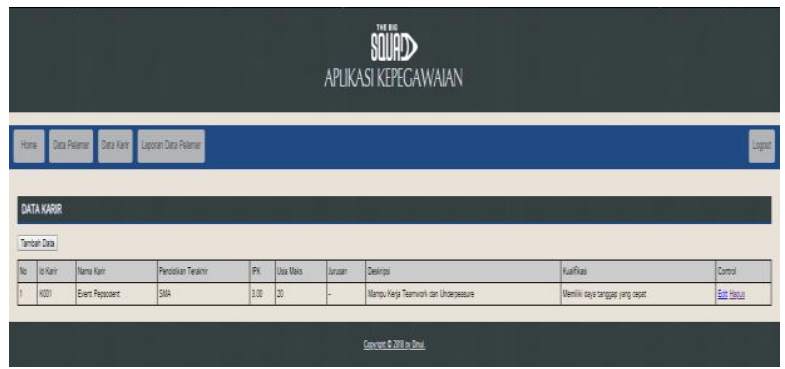

Gambar 17. Halaman Data Karir

Pada halaman data karir, menampilkan semua data karir yang telah diunggah oleh administrator, melihat detil dan menghapus data karir hanya dapat dilakukan oleh admin.

\section{LAPORAN DATA PELAMAR}

\begin{tabular}{|c|c|c|c|c|c|}
\hline No & Emal & Nama Peganà & Alambt & Posis & Telepon \\
\hline 1 & moninu79:9onal com & Dinul & ji. samo 3 & Event Pessodent & 0812129436974 \\
\hline
\end{tabular}

Catak Bamann Batal

Gambar 18. Halaman Laporan data Pelamar

Halaman ini akan menampilkan data laporan pelamar, lengkap dengan detil perkerjaan yang dilamar. 


\section{Kesimpulan}

PT Asta Pilar Gemilang dalam proses penerimaan karyawan dilakukan secara daring atau koneksi secara online dan dapat diakses dimana dan kapanpun oleh pelamar, pelamar dapat melihat informasi lowongan perkejaan dan dapat melakukan pengiriman data riwayat hidup untuk melamar kerja, penyimpanan dan pengelolaan data pelamar dapat dimaksimalkan dengan penggunaan sistem basis data, kenyamanan dan kemudahan dari sisi perusahaan dan pelamar dapat tercipta karena teknologi sistem yang diterapkan, keamanan data dapat di tingkatkan dengan sistem validasi login dan sistem backup data oleh sistem untuk mencegah dari hal-hal yang tidak dinginkan, hemat waktu dan biaya dalam penggunaan sistem penerimaan pegawai serta data dapat terus di pantau dan dimutakhirkan.

\section{Daftar Pustaka}

Anggraeni, E. Y. (2017). Pengantar Sistem Informasi (E. Risanto, ed.). Yogyakarta: Andi Offset.

Djahir, Y., \& Pratita, D. (2015). Bahan Ajar Sistem Informasi Manajemen. Yogyakarta: Deepublish.

Fadallah, M. F., \& Rosyida, S. (2018). Program Pemesanan Percetakan Berorientasi Objek dengan Pemodelan Unified Modeling Language. (1), 61-70.

Febriani, A., \& Hidayati, N. (2017). Penerapan Aplikasi Program Penjualan Dan Pembelian Menggunakan Model Rapid Application Development. JURNAL INFORMATIKA, 4(2), 261-271.

Harumy, T. H. F., Windarto, A. P., \& Sulistianingsih, I. (2016). Belajar Dasar Algoritma dan Pemograman C++. Yogyakarta: Deepublish.

Hutahaean, J. (2015). Konsep Sistem Informasi. Yogyakarta: Deepublish.

Jariyah, A. B. H. Y. A. F. F. A., \& Yanto, Hasta, 2018. (2018). Sistem Informasi E-Recruitment Karyawan Berbasis. Sukamto Dan Shalahuddin, 4(2), 1-6.

Julia, J., Isrok'atun, I., \& Safari, I. (2018). PROSIDING SEMINAR NASIONAL "Membangun Generasi Emas 2045 yang Berkarakter dan Melek IT" dan Pelatihan "Berpikir Suprarasional." UPI Sumedang Press.

Junaidi, A. (2016). Dashboard Sistem Informasi Support Maintenance ( Studi Kasus : Pt Polyta Global Mandiri ). Teknologi Informasi Dan Komputer, 1(1), 17-26.

Mulyani, S. (2016). Metode Analisis dan Perancangan Sistem (2nd ed.). Bandung: Abdi Sistematika.

Parulian, O. S. (2018). 3 Days With Mysql For Your
Application. Jakarta: Onesinus Saut Parulian.

Sanjaya, W. (2015). Perencanaan dan Desain Sistem Pembelajaran (6th ed.). Jakarta: Kencana.

Septihandayani, D., \& Yuniva, I. (2016). Sistem Informasi Unit Kegiatan Siswa Pramuka Berbasis Web Pada Smk Negeri 4. SISTEM INFORMASI STMIK ANTAR BANGSA, 5(1), 27-33.

Sitorus, L. (2015). Algoritma dan Pemrograman (A. Pramesta, ed.). Yogyakarta: Andi Offset.

Sukamto, R. A., \& Shalahuddin, M. (2016). Rekayasa Perangkat Lunak Terstruktur dan Berorientasi Objek (4th ed.). Bandung: Informatika.

Yanto, R. (2016). Manajemen Basis Data Menggunakan MySQL. Yogyakarta: Deepublish.

Yulia, E. R. (2017). Perancangan Program Penjualan Perhiasan Emas Pada Toko Mas Dan Permata Renny Medan. Evolusi, 5(2), 2338-8161. ISIJ International, 39(1), 23-32. 
